\title{
A Longitudinal Study of Canadian Student Leadership Practices
}

\author{
Barry Z. Posner, PhD \\ Accolti Endowed Professor of Leadership \\ Dean (1997-2009) \\ Leavey School of Business \\ Santa Clara University \\ bposner@scu.edu \\ Bob Crawford \\ Professor Emeritus \\ School of Computing \\ Queen's University \\ Kingston, Ontario \\ Roxy Denniston-Stewart \\ Associate Dean of Student Affairs \\ Queen's University \\ Kingston, Ontario
}

\begin{abstract}
Over a period of three years (2006-2008) students entering [university] were asked to complete the Student Leadership Practices Inventory (S-LPI), and 2,855 initial responses were received. Responding students were asked to complete the S-LPI again at the end of their first and third years of study. No significant differences were found in student use of the leadership practices based on age, geographic origin, or whether the student lived on or off campus during his or her first year. Significant differences were found based on students' gender and program of study. Implications for leadership development programming are considered.
\end{abstract}

\section{Introduction}

Colleges and universities have a fundamental role to play in the development of future leaders, and have a responsibility to provide students with leadership development opportunities (Austin, 1993; Austin \& Austin, 2000; CAS, 2003; Dugan \& Komives, 2007: McIntire, 1989; Posner \& Brodsky, 1992). Studies investigating what and how leader development occurs in students are invaluable for those involved in and responsible for student leader development programming (Posner, 2004). Others have asserted: "if our campuses espouse that they develop future leaders, it's time we get serious about doing what we say we're doing" (Roberts, 2003:143). Before any student leadership development program can be designed there must be an understanding of the needs of the students to whom the program will be delivered (Komives, 1996; Roberts \& Ullom, 1989; Zimmerman-Oster \& Burkhardt, 1999). Collecting baseline data 
is seen by The Council for the Advancement of Students in Higher Education as one of the first steps in creating a meaningful leadership development program (2003).

When a university prides itself on high caliber programs, students, faculty, staff, teaching, research, and facilities, and includes the vision, "[developing leadership in global society]," the natural question is whether this vision is being fulfilled. This consideration prompted this investigation. Moreover, while there is currently a vast amount of research on leadership development involving American students, the same cannot be said for its neighbor to the north. As leadership development programs become more prominent in Canadian institutions of higher education it is critical to have a pool of normative data based on the behaviors of Canadian students.

In focusing on the university's vision, and more specifically on the leadership aspect of this, the purpose of our study was to understand the extent that the institution was developing leaders. However, this issue can only be properly examined over the lifetime of its alumni. The more focused question was, therefore, are the students developing leadership skills during the course of their experience at the college? In order to answer this question, we investigated three research questions:

1. To what extent are entering students already engaged in leadership behaviors?

2. What changes in leadership behavior take place during students' first year?

3. What changes in leadership behavior occur over their years at the university?

In this particular university, students predominantly live in on-campus residences during their first year and live off-campus in subsequent years. Substantial institutional resources are devoted to a range of programming in campus residences during the first year. Knowing more about the strengths and weaknesses of first-year students (on entry) could effectively guide the particulars of leadership development in campus residences for these students. Knowing more about the leadership behaviors of students at the end of their first year in on-campus residences, and after three further years living off-campus would provide a useful guide in determining the campus-wide programming initiatives that might be developed for students over their collegiate experiences.

Researchers have already demonstrated that students come into college with varying degrees of leadership experiences and skills (Antonio, 2001; Dugan, Garland, Jacoby, \& Gasiorski, 2008; Kezar \& Moriarty, 2000; Smart, Ethington, Riggs, \& Thompson, 2002; Wielkiewicz, Fischer, Stelzner, Overland, \& Sinner, 2012). Others have documented that students develop and expand their leadership capabilities during their college years (e.g., (Pascarella \& Terenzini, 2005; Posner, 2009; Sessa, Morgan, Kalenderli, \& Hammond, 2014). Changes (improvements) in leadership behavior have come about through involvement in various student activities (e.g., student government, athletics, fraternities and sororities, etc.), community service, faculty mentoring, as well as formal leadership educational experiences offered both in the academic curriculum and co-curricular arenas. 


\section{Method}

Many of the leadership development programs designed for college students are based upon studies and models that were developed with managers in business and public-sector organizations (Freeman, Knott \& Schwartz, 1994). Serious questions have been raised about whether such models are applicable to college students and collegiate environments, which differ considerably from the environments in which managers and corporations operate. One way this issue has been addressed is through the development of textbooks aimed at college students (e.g., Bratton, Grint \& Nelson, 2004; Daft, 2010; Komives, et. al., 2006; Kouzes \& Posner, 2014; Wren, 1995). However, the typical personal assessment techniques supporting these initiatives continue to be borrowed from non-collegiate environments. Brodsky's (1988:23) observation, more than 25 years ago, is still generally applicable: AValid instruments designed specifically for college students to measure their leadership development do not exist." While the Leadership Resources: A Guide to Training and Development Tools lists 68 instruments "that are supported by technical data.... [to measure] a variety of leadership skills and styles" only two indicate a direct application to student populations (Schwartz \& Gimbel, 2000). One of these is the student version of the Leadership Practices Inventory (Kouzes \& Posner, 2006a, 2006b, 2006c).

The Student Leadership Practices Inventory (S-LPI) identifies specific behaviors and actions that students report using when they are at "their personal best as leaders." These behaviors are categorized into five leadership practices: Model the Way, Inspire a Shared Vision, Challenge the Process, Enable Others to Act, and Encourage the Heart. Identified as practices common to successful leaders, these leadership practices correspond well to the developmental issues of importance for college students. Representative statements of leadership behaviors for each leadership practice are:

1. Model the way (e.g., I set a personal example of what I expect from others);

2. Inspire a shared vision (e.g., I describe a compelling image of what our future could be like);

3. Challenge the process (e.g., I seek out challenging opportunities that test my skills and abilities);

4. Enable others to act (e.g., I develop cooperative relationships with the people I work with); and,

5. Encourage the heart (e.g., I praise people for a job well done).

Respondents consider how frequently they engage in each of the behaviors using five-point Likert-scales, with (1) indicating rarely or seldom and (5) indicating very frequently or almost always. There are six statements for each leadership practice and scores range between six to thirty. Internal reliability (Cronbach alpha) for the overall scale was .85 and above for all three time periods.

Findings from the most recent review of the Student Leadership Practices Inventory (SLPI) by Posner (2012) were consistent with those found in earlier studies (e.g., Adams \& Keim, 2002; Endress, 2000; Mendez-Grant, 2001; Posner, 2004; Posner \& Brodsky, 1993, 1994; Posner \& Rosenberger, 1997; and, Williams, 2002). Internal reliability coefficients are sound and individual respondent characteristics (e.g., GPA, year in school, and academic major) did not 
account for differences in leadership practices. Scores on the S-LPI from both the respondent (self) and observers' perspective differentiate between assessments of leadership effectiveness and member satisfaction (Posner, 2014).

In 2005-2006, following a faculty review of leadership development models and instruments, Kouzes and Posner's (2014) Leadership Challenge framework was selected, along with the S-LPI, to investigate the leadership capabilities of students at the institution. A prototype study was undertaken in 2006, followed by three longitudinal studies of students from entry to graduation. Three cohorts, entering in 2006, 2007, and 2008 academic years were studied, involving over 2,800 students. The S-LPI is typically used for helping students to baseline their leadership practices and learning how to expand their use of these leadership behaviors; however, in our case the instrument was strictly used for institutional assessment purposes. Students did not learn of their results or how these compared with other students. Participation was voluntary and confidential.

A pilot study was conducted in March 2006 for the purpose of gaining experience with both the administration of the instrument and analysis of the results. The instrument was administered to randomly selected students enrolled in their first and third year of studies (205 and 270 respectively). As part of the project, each student provided his or her student identification number and agreed that other information in University records could be integrated with their response. Analyses were conducted based on age, school year, gender, program of study, geographic home, and on-campus versus off-campus living. Based upon the experiences with the pilot study it was determined that the S-LPI was an appropriate instrument for the proposed longitudinal study. The instrument was both convenient to administer and evaluate. Results were relatively straightforward, clear and understandable, and could be used to inform future leadership development program planning.

\section{Results and Discussion}

In late August in 2006, 2007 and 2008, all entering first year students at the university were asked to complete the S-LPI. Students who participated were further contacted toward the end of their first year and again toward the end of their third year (While it would have been desirable to wait until the end of fourth year, permission to do so was not forthcoming - fourth year students face a number of surveys as they complete their studies, so survey fatigue was of concern). Overall results for the five leadership practices over the three longitudinal studies are presented in Table 1. These results are discussed further in the following sections. First, the individual and overall cohort groups are analyzed. Second, the possible impacts of individual demographic factors are investigated. 
Table1

S-LPI Results by Cohort Years and All Cohorts Combined

\begin{tabular}{|c|c|c|c|c|c|c|c|c|c|c|c|c|}
\hline \multirow[b]{2}{*}{ Source: } & \multicolumn{3}{|c|}{ COHORT I } & \multicolumn{3}{|c|}{ COHORT II } & \multicolumn{3}{|c|}{ COHORT III } & \multicolumn{3}{|c|}{ ALL COHORTS } \\
\hline & $\begin{array}{c}\text { Aug } \\
06 \\
\text { yr } 1 \\
\end{array}$ & $\begin{array}{c}\text { Mar } \\
07 \\
\text { yr } 1\end{array}$ & $\begin{array}{c}\text { Mar } \\
09 \\
\text { yr } 3\end{array}$ & $\begin{array}{c}\text { Aug } \\
07 \\
\text { yr } 1 \\
\end{array}$ & $\begin{array}{c}\text { Aug } \\
08 \\
\text { yr } 1\end{array}$ & $\begin{array}{c}\text { Mar } \\
10 \\
\text { yr } 3\end{array}$ & $\begin{array}{c}\text { Aug } \\
08 \\
\text { yr } 1 \\
\end{array}$ & $\begin{array}{c}\text { Mar } \\
09 \\
\text { yr } 1\end{array}$ & $\begin{array}{c}\text { Mar } \\
11 \\
\text { yr } 3\end{array}$ & $\begin{array}{l}\text { Aug } \\
\text { yr } 1\end{array}$ & $\begin{array}{l}\text { Mar } \\
\text { yr } 1\end{array}$ & $\begin{array}{l}\text { Mar } \\
\text { yr } 3\end{array}$ \\
\hline $\begin{array}{l}\text { \# of } \\
\text { Students }\end{array}$ & 1,223 & 253 & 289 & 576 & 226 & 104 & 1,056 & 459 & 262 & 2,855 & 938 & 655 \\
\hline $\begin{array}{l}\text { Model the } \\
\text { Way }\end{array}$ & 21.32 & 21.65 & 22.04 & 21.72 & 21.49 & 22.17 & 21.62 & 21.80 & 22.24 & 21.51 & 21.69 & 22.14 \\
\hline $\begin{array}{l}\text { Inspire a } \\
\text { Shared } \\
\text { Vision }\end{array}$ & 20.89 & 20.17 & 21.73 & 21.29 & 20.89 & 21.56 & 21.18 & 21.06 & 21.68 & 21.08 & 21.05 & 21.68 \\
\hline $\begin{array}{l}\text { Challenge } \\
\text { Process }\end{array}$ & 21.27 & 21.11 & 22.08 & 21.63 & 21.34 & 21.44 & 21.54 & 21.13 & 22.09 & 21.44 & 21.17 & 21.98 \\
\hline $\begin{array}{l}\text { Enable } \\
\text { Others to } \\
\text { Act }\end{array}$ & 23.80 & 24.34 & 24.71 & 23.99 & 24.09 & 24.50 & 24.09 & 24.41 & 24.75 & 23.95 & 24.31 & 24.69 \\
\hline $\begin{array}{l}\text { Encourage } \\
\text { the Heart }\end{array}$ & 22.60 & 22.30 & 22.79 & 23.10 & 22.23 & 22.98 & 23.05 & 22.71 & 22.83 & 22.86 & 22.48 & 22.84 \\
\hline
\end{tabular}

\section{On Entry}

Overall results for the 2,855 students in the three cohorts combined, on entry, are shown in Figure 1 (First year students move into their on-campus residences over the Labour Day weekend. The request to complete the survey was sent to students prior to this. In 2006 and 2008, this request was made a full week before Labour Day, while in 2007 the request was made only three days prior to when they would be departing for university. Many of these students were on campus by the time they were being reminded to complete the S-LPI, and the business of Frosh Week and the start of classes apparently overrode their desire to please their new institution by responding to its (non-mandatory) request to complete a survey (in comparison with the other two entering cohorts). There were no significant differences from cohort to cohort. This graph is based on the percentiles reported by Kouzes and Posner (2006a). Given the breadth of our sample, it is not altogether surprising that the results generally fall within the normal distribution of their normative database (ranging from the $37^{\text {th }}$ to the $53^{\text {rd }}$ percentile). While many of the students in this study were leaders in their high schools, there are also many who have never taken on a leadership role and have not engaged significantly in the five leadership practices. 


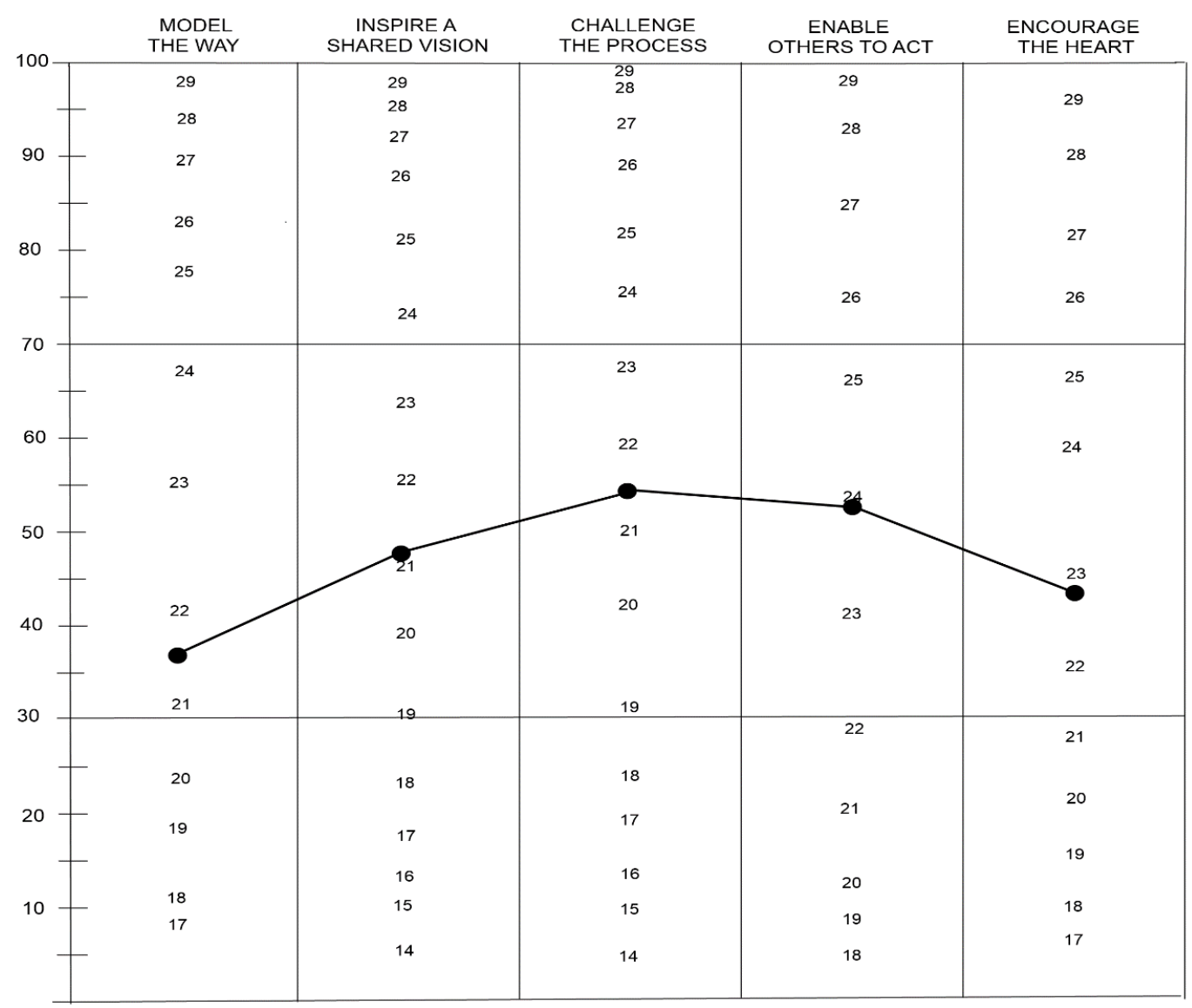

Figure 1

S-LPI Scores for Entering Students from Combined Cohorts

Students, upon entry (several months since completing high school) report engaging most frequently in the leadership practices of Enable Others to Act and Encourage the Heart. These are followed in frequency by Model the Way and Challenge the Process, and then Inspire a Shared Vision. Plotting these average scores onto the Kouzes and Posner (2012) normative data base reveals another perspective. Compared with all of the students around the world who have completed the S-LPI this sample of Canadian undergraduates are within one standard deviation of the mean in all five leadership practices. Scores for Challenge and Enable are above the $50^{\text {th }}$ percentile; scores on Inspire and Encourage are just somewhat below the $50^{\text {th }}$ percentile; and Model scores are around the $37^{\text {th }}$ percentile. The percentile graph also shows how the variance of scores around the mean vary for each leadership practice (e.g., the standard deviation for Challenge is greater than that for Model).

\section{End of First Year and Third Year}

How frequently students engage in the five leadership practices are fairly consistent for all three cohorts, as shown in Table 1. The same general pattern applies to the cohorts on entry as it does at the end of year one and at the end of year three. Figure 2 shows relatively similar shapes of the curves for all five leadership practices at each of these three points in time. 


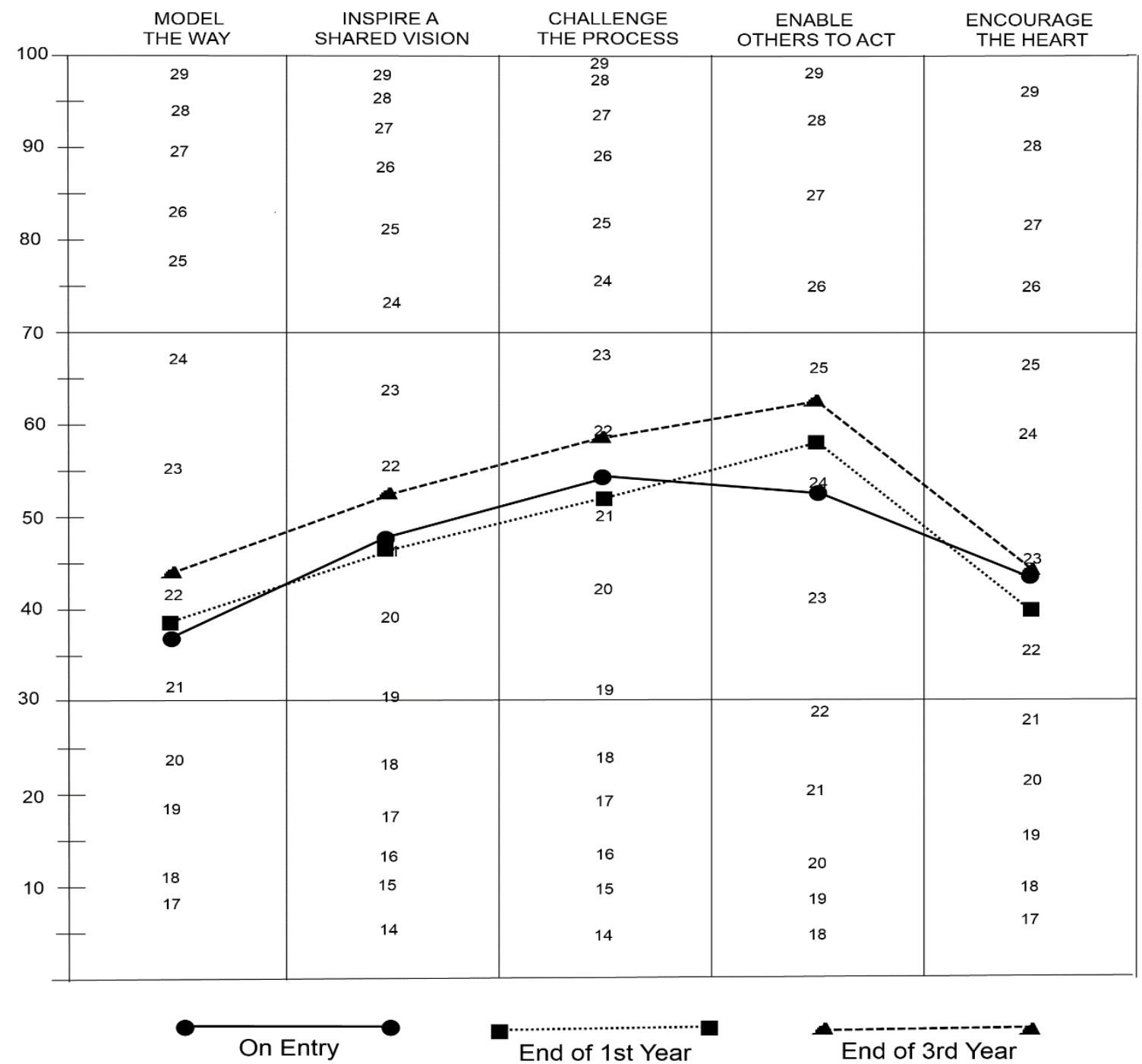

Figure 2

S-LPI for Combined Cohorts over the Three Time Periods

As is apparent from Figure 2, there was very little change over the first year from entry. The only change of statistical significance is the increase in the leadership behaviors connected with Enable Others to Act. The increase in Enable Others to Act may be due to the large amount of group work that students are assigned in their first-year classes, as well as the fact that they are living together in a common facility; both of which are quite atypical of their high school experience.

Generally, that there would be little significant change in leadership behaviors over the seven months from students' entry to the end of their first year is not unexpected; and can be accounted for in several possible ways. For one, the majority of first-year students live in oncampus housing. In that context, they are exposed to some student development programming, but not specifically to any programming focused on leadership development. As such, any 
change in response to the S-LPI, in either direction, would primarily be based on simple maturation (or not, over seven months), any leadership development that was fostered in their academic program (which is very unlikely in their first year of studies when they are primarily completing general education requirements), the salience of a potential new comparison (referent) group for reflecting on their leadership behaviors (peers in high school versus those in university; as well as the fact that there were more formal leadership opportunities for collegeprep high school students than there are for first-year college students), and possible test-retest reliability issues for the instrument. The latter can be ruled out empirically. As a cohort, the average correlations between each of the five leadership practices at entry and at the end of year one was .51 $(p<.001)$ and between the end of year one and end of year three was $.43(p<.001)$. These are relatively strong test-retest reliabilities over such long time periods and presumably varying circumstances (Kerlinger, 1986).

While there was little significant change between entry and the end of Year 1, all the changes from the end of Year 1 to the end of Year 3 as well as from entry to Year 3, are statistically significant with one exception (the change in Encourage the Heart from Entry to the end of Year 3 was not statistically significant). Given that this institution in particular, and colleges in general, maintain that a college education provides a leadership development experience it should not be surprising that there is an increase in the frequency to which students indicate they are engaged in various leadership behaviors over time (longer than their first seven months at the institution). There are many factors which have been studied and postulated for these changes (e.g., Astin, 1993; Astin, Keup, \& Lindholm, 2002; Berger \& Milem, 2002; Cress, Astin, Zimmerman-Oster, \& Burkhardt, 2001; Dugan, 2006; Dugan \& Komives, 2010; Kezar \& Moriarty, 2000; Posner, 2014; Sessa et al., 2014; Smart et al., 2002; Thompson, 2006).

\section{Demographic Factors}

With the permission of the students and the approval of the General Research Ethics Board, we were able to associate each student's completed S-LPI with their biographic and academic records. Recalling that we were looking for any characteristics of the students that might drive various programming initiatives, we considered five factors:

(1) Age: Students were categorized into four groups on entry: (1) 17 years and younger; (2) 18 years; (3) 19 years; and (4) 20 years and older. Age was calculated as of December $31^{\text {st }}$ of their entering year, so the normal entering cohort is 18 years of age. In Canada, it is not unusual for students to complete a further year of high school. Eighty percent of the students were 18 years old. No statistically significant differences for entering students were found based on age.

(2) Geographic Origin: Respondents were categorized by the geographic region they came from, based on their home address. Four regions were considered: (1) Ontario; (2) Canada east of Ontario; (2) (3) Canada west of Ontario; and (4) Outside Canada. Eighty-one percent of the students were from Ontario. No statistically significant differences were found based on geographical place of origin.

(3) Living in Residences On-Campus or off Campus: Eighty-seven percent of the first year students were living in on-campus residences, and no statistically significant differences were 
found between them and those living off-campus in their first year. For third-year students, over 95 percent live off-campus and no statistically significant differences were found between them and their counterparts living on-campus.

(4) Gender: All the samples were analyzed by gender. Table 2 shows the results by gender for the three cohorts combined. The notable differences by gender, on entry, are seen in Figure 3. For this combined cohort, females reported engaging in the leadership practices of Model the Way, Inspire a Shared Vision, Enable Others to Act and Encourage the Heart statistically significantly more than males. No significant differences between females and males, at entry to the institution, were found for the leadership practice of Challenge the Process.

Table 2

S-LPI Results by Gender for Each Cohort

\begin{tabular}{lcccccc}
\hline \multicolumn{1}{c}{ Source: } & \multicolumn{2}{c}{ On Entry } & End of Year One & End of Year Three \\
\hline & Female & Male & Female & Male & Female & Male \\
\hline \# of students: & 1788 & 1067 & 675 & 263 & 468 & 187 \\
\hline Model the Way & 21.67 & 21.25 & 21.75 & 21.52 & 22.31 & 21.72 \\
\hline Inspire a Shared Vision & 21.26 & 20.77 & 21.01 & 21.16 & 21.74 & 21.53 \\
\hline Challenge the Process & 21.50 & 21.35 & 21.11 & 21.33 & 22.02 & 21.88 \\
\hline Enable Others to Act & 24.25 & 23.43 & 24.52 & 23.77 & 24.99 & 23.94 \\
\hline Encourage the Heart & 23.43 & 21.91 & 22.76 & 21.78 & 23.25 & 21.81 \\
\hline
\end{tabular}




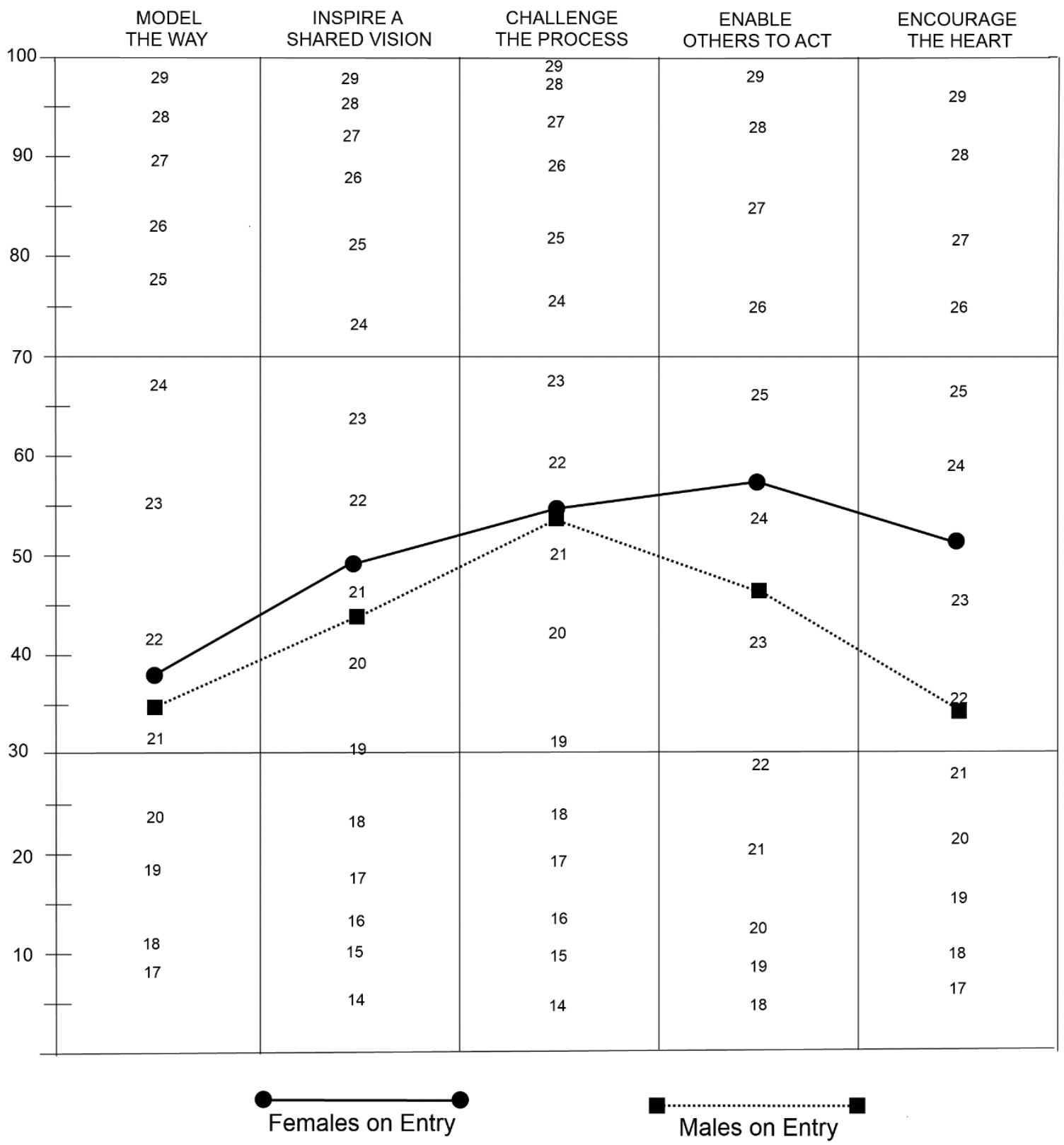

Figure 3

S-LPI on Entry by Gender

It is at times useful to consider the "rank order" of the leadership practices for any given group. The basis for the ordering is not generally stated in the literature; presumably it is based on raw scores (averages). But there is a difference between raw scores and percentile scores, as seen in the data reported here. Based on raw scores, rank order results on entry are EnableEncourage-Challenge-Model-Inspire for Males, and the same, only with the order of Challenge and Model reversed, for Females. For both genders, the scores for these two practices were very close, so the difference in rank order is not significant. Rank order can also be based on where the scores fall in terms of percentile ranking. This results in a different rank order for each 
gender. For Percentile Ranking, the order for males is Challenge-Enable-Inspire-EncourageModel while for females it is Enable-Challenge-Encourage-Inspire-Model. This represents a reversal of the first two as well as the third and fourth in the list. Percentile rank provides a more interesting and useful result in determining where to focus attention.

Previous studies that reported gender comparisons vary with regard to gender differences. Some studies have found little or no difference. Lin (2003), based on a sample of 1,235 college students from 18 institutions in Taiwan, concluded that the five practices did not vary between male and female students. Posner (2004:446), in summarizing the work of previous studies of fraternity and sorority presidents states that, "the practices of effective student leaders did not vary according to the leader's gender" and he also noted that, across a number of student populations, "Few gender differences among college students have been reported." Similarly, Ervin (2005), in considering 308 student government members from eight colleges across the Midwestern United States, found no differences between male and female respondents on the five leadership practices.

Other researchers have reported differences in leadership practices based on gender. Bardou, Byrne, Pasternak, Perez, \& Rainey (2003) considered the responses of 100 women and 88 men to a modified S-LPI. Their focus was on self-efficacy, so statements on the S-LPI were changed to address how well individuals thought they could perform the particular task rather than the frequency with which they completed the task as in the original S-LPI. They found that women's self-efficacy for Model the Way was statistically higher than that of men. They did not find significant differences for the other four practices. Posner (2009) found only two differences in students based on gender in the first year -- males reported that they engaged in the leadership practice of Model more often than did females and females reported engaging more frequently in the leadership practice of Challenge than did males -- but these significant gender differences disappeared by the time of graduation. More recently Posner (2014) reported female students engaging in the five leadership practices significantly more so than their male counterparts, but pointed out that these differences did not account for any variance in the perceived effectiveness of male and female leaders by their constituents. In a study involving 200 student athletes in the United States and Japan, while females scored higher on all five leadership practices than males in each country only Enable Others to Act and Encourage the Heart reached statistically significant levels (Usami, 2003).

In Rand's (2004) study of 260 students participating in a leadership development training day, differences between males and females were found on all the leadership practices except for Challenge. Female student leaders self-reported engaging in the leadership practices of Model, Inspire, Enable, and Encourage significantly more than their male colleagues. Dugan (2006) explored leadership development among college men and women using the Socially Responsible Leadership Scale and reported than the average scores of women were higher than men across all eight of the leadership constructs.

While previous studies have shown that some of the differences between males and females fade over time during their college experience (Posner, 2009, 2014), in this study at the end of year one and the end of year three, the higher scores for females remained statistically significant for Enable Others to Act and Encourage the Heart. Figure 4 shows the results for 
students by gender between entry to university and the end of their third year. The significant growth that occurred for the overall cohort is true for each gender. Repeated Measures Analysis demonstrated that there were no significant differences between the patterns of growth for the genders over time (results not shown).
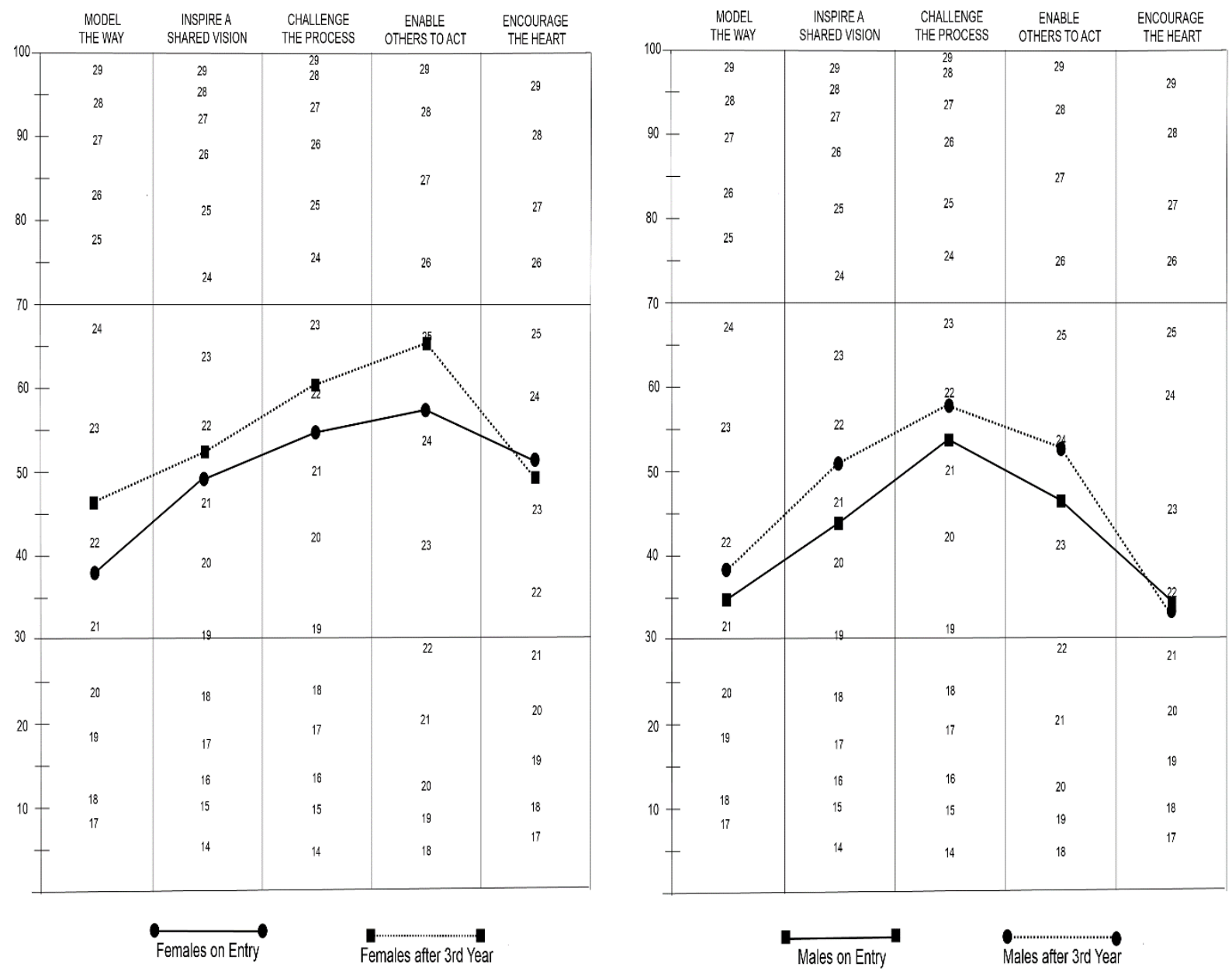

Figure 4

S-LPI for Females and Males from Year 1 to Year 3

This similarity between females and males has important practical implications. The differences between the genders were statistically significant on entry to university, prompting the thought that it might be important to develop different programming for males and females. However, the similarity of the pattern of development for males and females over the years makes it clear that, while the differences are statistically significant, they are not particularly meaningful for programmatic decision making at the institution. In terms of programming, at this particular institution, it may be advantageous to target males, but not warranted to develop specific programming targeted for them.

(5) Program of Study: Students are admitted to a specific Faculty or School upon entry for a "program of study." These include: Arts (Humanities, Social Sciences and the Arts), Science, 
Engineering, Business, Education, and, Nursing and Kinesiology (this last grouping was formed following data collection to ensure appropriate group size for analysis). Similar patterns were seen in the leadership data for students in each of the three cohorts at all collection points. Table 3 presents the data for the combined cohorts on entry, and Figure 5 presents samples of this data graphically.

Table 3

S-LPI Results by Program, on Entry

\begin{tabular}{lcccccc} 
& Arts & Science & Engineering & Business & Education & $\begin{array}{c}\text { Nursing \& } \\
\text { Kinesiology }\end{array}$ \\
\hline \multicolumn{1}{c}{ \# of students: } & 901 & 859 & 502 & 316 & 132 & 145 \\
\hline Model the Way & 21.63 & 21.59 & 20.76 & 21.90 & 21.90 & 21.74 \\
\hline $\begin{array}{l}\text { Inspire a Shared } \\
\text { Vision }\end{array}$ & 21.38 & 21.01 & 19.95 & 21.90 & 21.59 & 21.23 \\
\hline $\begin{array}{l}\text { Challenge the } \\
\text { Process }\end{array}$ & 21.50 & 21.35 & 21.00 & 22.02 & 21.52 & 21.81 \\
\hline $\begin{array}{l}\text { Enable Others to } \\
\text { Act }\end{array}$ & 24.29 & 23.92 & 23.44 & 23.52 & 24.27 & 24.34 \\
\hline $\begin{array}{l}\text { Encourage the } \\
\text { Heart }\end{array}$ & 23.27 & 23.02 & 21.57 & 22.99 & 23.48 & 23.14 \\
\hline
\end{tabular}




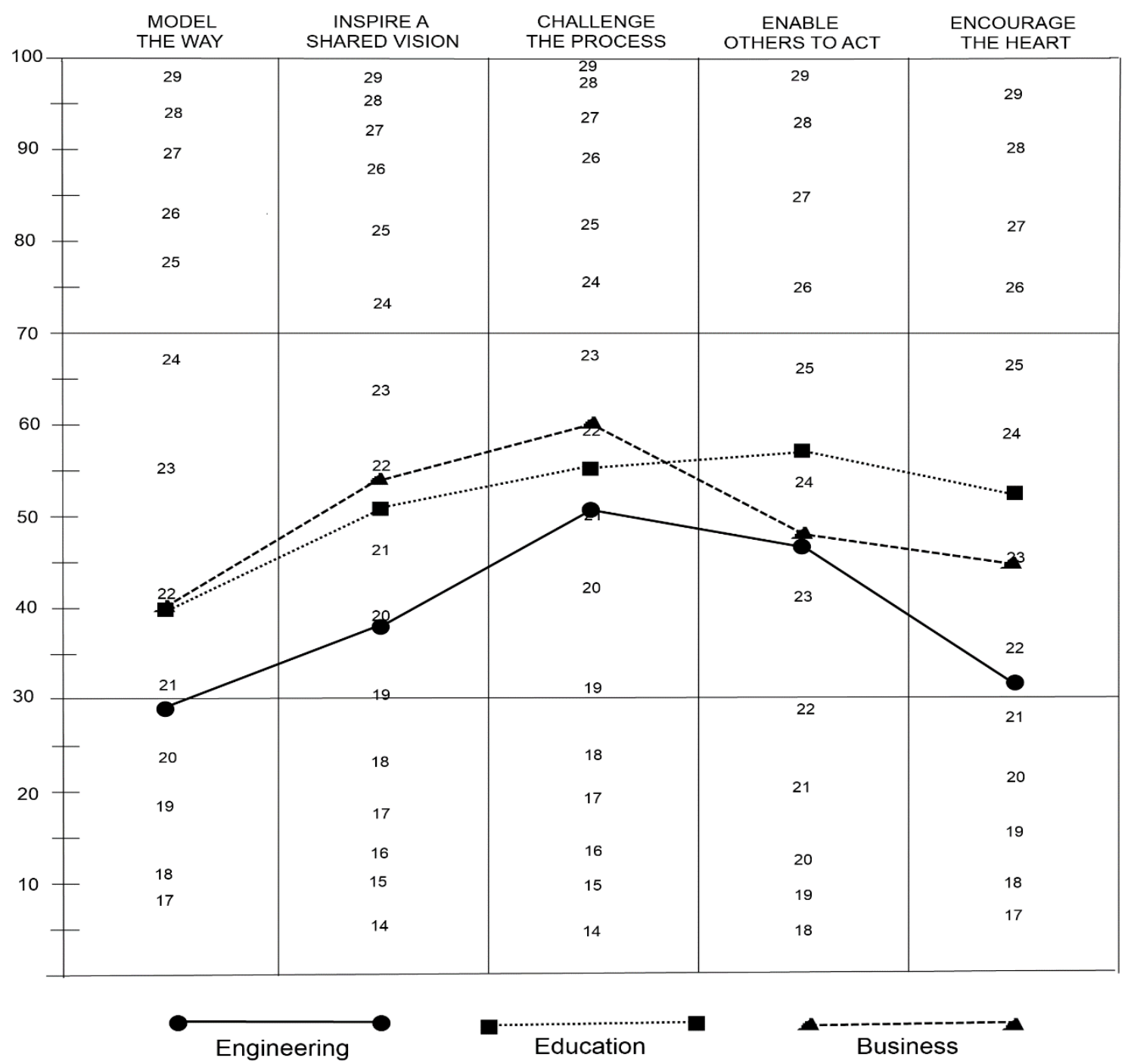

Figure 5

S-LPI Results by Program on Entry

Statistical significance was assessed for any differences between all programs of study. On entry, there were only two statistically significant differences not involving Engineering students. Business students reported engaging in the leadership practice of Inspire a Shared Vision significantly more than Science students; while Arts students indicated their propensity to Enable Others to Act significantly more than Business students. All other significant differences involved Engineering Students. On Entry, Engineering students reported engaging in all five practices significantly less than other students.

Results by Program of Study were examined after one year and after three years of university study. At the end of Year One, with one exception, there were no statistically significant differences between the leadership practices of students by program of study. The one exception was Education students reporting high frequency than business students in the leadership practice of Enable Others to Act. At the end of third year, there was no statistically 
significant difference between any of the groups on any of the leadership practices. However, students in the different programs followed diverse patterns of development over the three years. Figure 6 shows the progression over three years for students in the six programs of study; and no two patterns are identical. However, some patterns are worthy of additional comment.

For instance, Engineering students, with entering scores that are lower than every other group, showed increases in all five leadership practices over their first year. Three explanations are postulated. First, while students at this institution pride themselves in the extent to which they bond together, this is particularly true of engineering students who through rigorous and structured coursework develop a strong affinity for their fellow Engineering students. Second, the program is quite challenging, with a very full schedule of classes and labs, so that students develop patterns of working together informally. Third, there is considerable group work assigned, necessitating working together in quite formal ways. Interestingly enough, this change from Entry to the end of the first year does not dramatically shift again at the end of their third year.
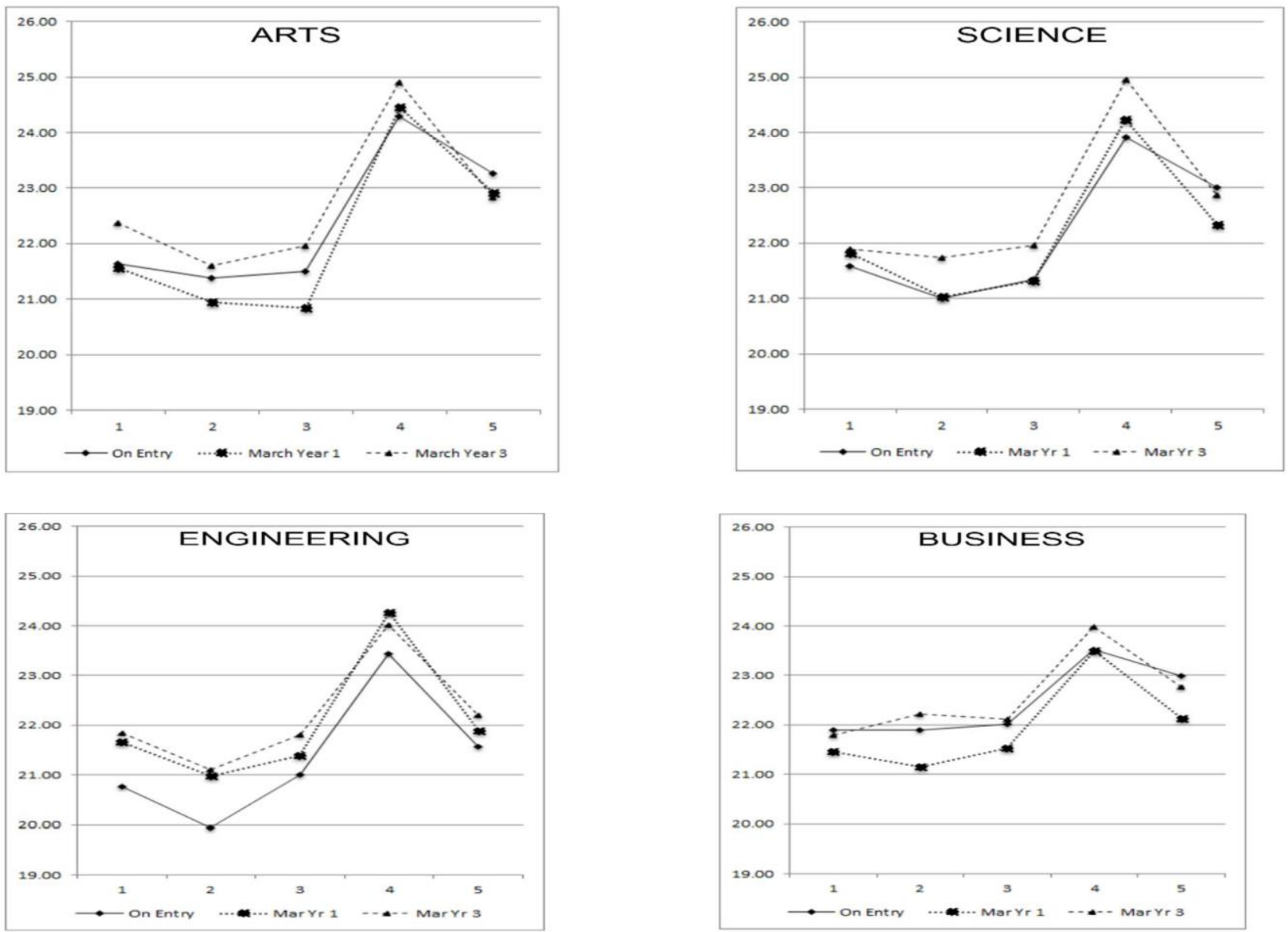

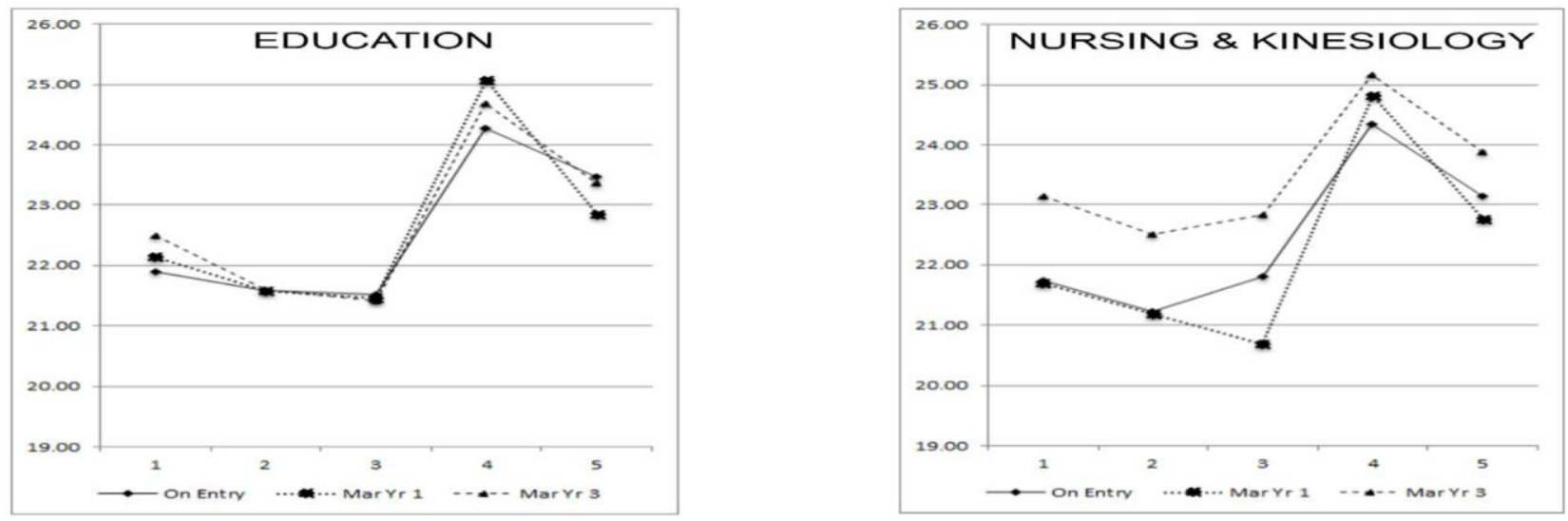

Figure 6

S-LPI by Program of Study for Years 1 to 3

The pattern for Education students is also interesting. Having entered with frequency in the five leadership practices scores that were above average for the overall cohort, there was very little change seen over time. Because of the nature of the program, in which the BEd is received in conjunction with a BA or BSc, over their first three years students are primarily involved in their broader academic work, with only one course in teacher education each year. Hence, the impact of "teacher education" studies on leadership development is not very pronounced. The pattern for Business students, which attracts exceptionally highly qualified students who engage in considerable group work suggests that the program provides excellent examples for them that set a high standard against which they respond at the end of year one and the end of yearthree. Overall, it is reasonable to suggest that, particularly in the absence of broader leadershiptraining, the program in which a student is enrolled has some effect on their leadership development as reflected in their responses on the S-LPI.

\section{Summary and Limitations}

Leadership development is now an integral part of the educational program of most college students, with courses and activities running the gamut from curricular classes offered by a variety of academic disciplines (like business, psychology, political science, history, military science, and education) to co-curricular programs offered by various student affairs offices (from admissions and athletics to student government, Greek affairs, and community service centers). Without specifying particular involvement in any of these opportunities the data revealed that students generally report that they engage in leadership more frequently over the course of their collegiate career (from entry, to the end of their first year, and to the end of their third year). Clearly some phenomenon is occurring at this institution which, at a minimum, reflects a selffulfilling prophecy of its mission statement. In addition, the data collected in this study provides a useful benchmark for the Canadian context.

There are limitations as to what absolute conclusions can be drawn with regard to leadership development that was evidenced over the time at this particular university (versus any tertiary institution). Among 28 Canadian universities that participated in the National Survey of 
Student Experience in 2006, this institution ranked first in the engagement of first-year students (Macleans, 2007). Moreover, this university's admissions standards have been the highest, or among the highest, in Canada for many years. In addition to exploring similar issues at a broader range of institutions of higher education, it would have been ideal to have tracked a similar cohort of young people as they progressed from ages 17 to 21, while not participating in higher education, to rule out any effects simply due to maturation.

The impact of age, geographical place of origin, and residential location (on-campus or off-campus) were not found to be significant factors in any changes in leadership behavior over time. While there were differences found on the basis of gender (males versus females), the changes in leadership behavior over time by males and females mirrored one another. Seemingly most prominent in influencing any changes in leadership behavior over time was the students' program of study. This would seem to entail more than just the academic content but the sociological manner in which students are expected to learn the content and work together in that process. It may be within these arenas that differential leadership development programming by the institution might be targeted.

\section{References}

Adams, T., \& Keim, M. (2002). Leadership practices and effectiveness among Greek student leaders. College Student Journal, 34, 259-270.Antonio, A. L. (2001). The role of interracial interaction in the development of leadership skills and cultural knowledge and understanding. Research in Higher Education, 42(5), 593-617.

APSC 100 Engineering practice: Engineering design, Module. Retrieved January 2014 from http://engineering.queensu.ca/Current-Students/First-Year-Studies/CourseInformation/APSC-100.html

Astin, A. W. (1993). What matters in college? Four critical years revisited. San Francisco, CA: Jossey-Bass.

Astin, A. W., \& Astin, H. S. (2000). Leadership reconsidered. Battle Creek, MI: W.K. Kellogg Foundation.

Astin, A. W., Keup, J. R., \& Lindholm, J. A. (2002). A decade of changes in undergraduate education: A national study of system "transformation. The Review of Higher Education, 25(2), 141-162.

Bardou, K.J., Byrne, S.M., Pasternak, V.S., Perez, N.C. \& Rainey, A.L. (2003). Self-efficacy and student leaders: The effects of gender, previous leadership experiences, and institutional environment. Journal of the Indiana University Student Personnel Association, 33-48.

Baxter, W.H. (2001). Engineering leadership. Master’s Thesis, Texas A\&M University. 
Berger, J. B., \& Milem, J. F., (2002). The impact of community service involvement on three measures of undergraduate self-concept. NASPA Journal, 40, 85-103.

Bratton, J., Grint, K., \& Nelson, D.L. (2004). Organizational leadership. Mason: OH: SouthWestern.

Brodsky, B. (1988). Development of a modified version of the Leadership Practices Inventory for use with college students. Unpublished masters' thesis, San Jose State University.

CAS (Council for the Advancement of Students in Higher Education) (2003). The Role of Leadership Programs for Students.

Cress, C. M., Astin, H. S., Zimmerman-Oster, K., \& Burkhardt, J. C. (2001). Developmental outcomes of college students' involvement in leadership activities. Journal of College Student Development, 42, 15-27.

Daft, R. (2010). The leadership experience (5th Ed). Mason, OH: South-Western.

Dugan, J. P. (2006). Explorations using the social change modal: Leadership development among college men and women, Journal of College Student Development. 47 (2), 217225.

Dugan, J. P., \& Komives, S. R. (2007). Developing leadership capacity in college students: Findings from a national study. College Park, MD: National Clearinghouse for Leadership Programs, Multi-Institutional Study of Leadership.

Dugan, J. P., \& Komives, S. R. (2010). Influences on college students' capacities for socially responsible leadership. Journal of College Student Development, 51, 525-549.

Dugan, J. P., Garland, J. L., Jacoby, B., \& Gasiorski, A. (2008). Understanding commuter student self-efficacy for leadership: A within-group analysis. NASPA Journal, 45, 282310.

Endress, W. (2000). An exploratory study of college students' self-efficacy for relational leadership: the influence of leadership education, cocurricular involvement, and oncampus employment. Unpublished doctoral dissertation, University of Maryland.

Ervin, L.A. (2005). Women's leadership practices in student government, Doctoral Dissertation, Kansas State University, June 2005.

Freeman, F., Knott, K., \& Schwartz, M. (1994). Leadership education 1994-1995: A Sourcebook. Greensboro, NC: Center for Creative Leadership.

Kerlinger, F. (1986). Foundations of behavioral research. New York: Holt, Rinehart and Winston. 
Kezar A., \& Moriarty, D. (2000). Expanding our understanding of student leadership development: A study of gender and ethnic identity. Journal of College Student Development, 41, 55-69.

Komives, S. (1996). A social change model of leadership development: Guidebook version III. Los Angeles: University of California Los Angeles Higher Education Research Institute.

Komives, S., Lucas, N., \& McMahon, T. (2006). Exploring leadership: For college students who want to make a difference $\left(2^{\text {nd }} \mathrm{Ed}\right)$. San Francisco: Jossey-Bass.

Kouzes, J.M., \& Posner, B.Z. (2006a). Student leadership practices inventory - Student workbook. San Francisco, Jossey-Bass.

Kouzes, J.M., \& Posner, B.Z. (2006b). Student leadership practices inventory - Self. San Francisco, Jossey-Bass.

Kouzes, J.M., \& Posner, B.Z. (2006c). Student leadership practices inventory. San Francisco, Jossey-Bass.

Kouzes, J.M., \& Posner, B.Z. (2012). The leadership challenge $\left(5^{\text {th }}\right.$ Ed). San Francisco, Wiley.

Kouzes, J.M., \& Posner, B.Z. (2014). The student leadership challenge ( $2^{\text {nd }}$ Ed). San Francisco, Wiley.

Lin, G. (2003). Leadership development of college students in Taiwan, Department of Educational Leadership and Policy Studies, Indiana University Doctoral Dissertation. February 2003.

McIntire, D.D. (1989). Student leadership development: A student affairs mandate. NASPA Journal, 27(1), 75-79.

Macleans (2007). Students grade their universities, November 19, 82-86.

Mendez-Grant, M. (2001). A study of freshman interest groups and leadership practices at Texas Women's University. Unpublished doctoral dissertation, University of North Texas.

Pascarella, E. T., \& Terenzini, P. T. (2005). How college affects students: A third decade of research. San Francisco: Jossey Bass.

Posner, B.Z. (2004). A leadership development instrument for students: Updated. Journal of College Student Development, 45(4), 443-456.

Posner, B.Z. (2009). A longitudinal study examining changes in students' leadership behavior. Journal of College Student Development. 50 (5), 551-563. 
Posner, B.Z. (2012). Effectively Measuring Student Leadership. Administrative Sciences, 2(4), 221-234. DOI: 10.3390/admsci2040221

Posner, B.Z. (2014). The impact of gender, ethnicity, school setting, and experience on student leadership: Does it really matter? Management and Organizational Studies. 1(1):21-31.

Posner, B.Z. \& Brodsky, B. (1992). A leadership development instrument for college students. Journal of College Student Development, 33(4), 231-237.

Posner, B., \& Rosenberger, J. (1997). Effective orientation advisors are leaders too. NASPA Journal, 35(1), 46-56.

Rand, L.J. (2004). The leadership practices of residence student leaders. Sports and Recreation Administration Graduate Academic Unit of Kinesiology, University of New Brunswick (Canada), unpublished Master's Thesis, April 2004.

Roberts, D. \& Ullom, C. (1989). Student leadership program model. NASPA Journal, 27, (1), 6774.

Roberts, D.C. (2003) Crossing the boundaries in leadership program design. In C. Cherrey, J.J. Gardiner, \& N. Huber (Eds.). Building leadership bridges (pp. 137-149). College Park, MD: International Leadership Association.

Schwartz, M., \& Gimbel, K. (2000). Leadership resources: A guide to training and development tools. Greensboro, NC: Center for Creative Leadership.

Sessa, V.I., Morgan, B.V., Kalenderli, S., \& Hammond, F.E. (2014). Key events in student leaders' lives and lessons learned from them. Journal of Leadership Education. DOI:10.12806/V13/I2/R1

Smart, J. C., Ethington, C. A., Riggs, R. O., \& Thompson, M. D. (2002). Influences of institutional expenditure patterns on the development of students' leadership competencies. Research in Higher Education, 43, 115-132.

Thompson, M. D. (2006). Student leadership process development: An assessment of contributing college resources. Journal of College Student Development, 47(3), 343-350.

Usami, M. (2003). The effect of gender and nationality on leadership practices of studentathletes in the United States and Japan. College of Applied Sciences and Technology, Ball State University (Indiana) Unpublished Master's Thesis, December 2003.

Wielkiewicz, R. M., Fischer, D. V., Selzner, S.P, Overland, M., \& Sinner, A. M. (2012). Leadership attitudes and beliefs of incoming first-year college students: A multiinstitutional study of gender differences. Journal of Leadership Education, 11(2), 1-24. 
Williams, E. (2002). Differences in Greek leadership styles. Unpublished research paper, Central Michigan University.

Wren, J. T. (Ed.) (1995). The leader's companion: Insights on leadership through the ages. New York: Free Press.

Zimmerman-Oster, K. \& Burkhardt, J. (1999). Leadership in the making: Impact and insights from leadership development programs in U.S. colleges and universities. Journal of Leadership Studies, 6(3-4), 50-66.

\section{Author Biographies}

Barry Posner is the Accolti Endowed Chair of Leadership, Leavey School of Business, Santa Clara University, where he also served for 12 years as the Dean. He is the co-author of a number of leadership books, including The Leadership Challenge, Credibility, The Truth About Leadership, The Academic Administrator's Guide of Exemplary Leadership, and The Student Leadership Challenge. He received his undergraduate degree from the University of California, Santa Barbara, master's degree in public administration from The Ohio State University, and $\mathrm{PhD}$ in organizational behavior and administrative theory from the University of Massachusetts, Amherst.

Bob Crawford is Professor Emeritus in the School of Computing at Queen's University in Kingston, Ontario. His forty-two years on the faculty at Queen's included twenty years in administration, ten as Dean of Student Affairs. He led the Student Outcomes Working Group, focusing on the university's stated mission to prepare citizens and leaders for a global society. He completed his Bachelor of Science in Engineering Science at Penn State University and his $\mathrm{MSc}$ and $\mathrm{PhD}$ in Computer Science at Cornell University.

Roxy Denniston-Stewart serves as an Associate Dean of Student Affairs at Queen's University in Kingston, Ontario. Throughout her 35 year career in Student Affairs and Services she has held a variety of administrative roles. Roxy received her Bachelor of Commerce from the University of Guelph in 1978 and her Masters of Education in Administration from the University of Windsor in 1987. Prior to coming to Queen's she held positions at the University of Windsor and the University of Guelph. 